\title{
Potential complications when developing gene deletion clones in Xylella fastidiosa
}

\author{
Kameka L Johnson ${ }^{1}$, Luciana Cursino ${ }^{2}$, Dusit Athinuwat ${ }^{1,3}$, Thomas J Burr ${ }^{1}$ and Patricia Mowery ${ }^{2 *}$
}

\begin{abstract}
Background: The Gram-negative xylem-limited bacterium, Xylella fastidiosa, is an important plant pathogen that infects a number of high value crops. The Temecula 1 strain infects grapevines and induces Pierce's disease, which causes symptoms such as scorching on leaves, cluster collapse, and eventual plant death. In order to understand the pathogenesis of $X$. fastidiosa, researchers routinely perform gene deletion studies and select mutants via antibiotic markers.
\end{abstract}

Methods: Site-directed pilJ mutant of X. fastidiosa were generated and selected on antibiotic media. Mutant cultures were assessed by PCR to determine if they were composed of purely transformant cells or included mixtures of nontransformants cells. Then pure pilJ mutant and wildtype cells were mixed in PD2 medium and following incubation and exposure to kanamycin were assessed by PCR for presence of mutant and wildtype populations.

Results: We have discovered that when creating clones of targeted mutants of $X$. fastidiosa Temecula 1 with selection on antibiotic plates, $X$. fastidiosa lacking the gene deletion often persist in association with targeted mutant cells. We believe this phenomenon is due to spontaneous antibiotic resistance and/or $X$. fastidiosa characteristically forming aggregates that can be comprised of transformed and non-transformed cells. A combined population was confirmed by PCR, which showed that targeted mutant clones were mixed with non-transformed cells. After repeated transfer and storage the non-transformed cells became the dominant clone present.

Conclusions: We have discovered that special precautions are warranted when developing a targeted gene mutation in $X$. fastidiosa because colonies that arise following transformation and selection are often comprised of transformed and non-transformed cells. Following transfer and storage the cells can consist primarily of the non-transformed strain. As a result, careful monitoring of targeted mutant strains must be performed to avoid mixed populations and confounding results.

Keywords: Aggregation, Pierce's Disease, Xylella fastidiosa, Transformation, Antibiotic selection

\section{Background}

Xylella fastidiosa is a Gram-negative, xylem-limited, insect-vectored bacterium that is a causal agent of many economically important plant diseases, including Pierce's disease of grapevines [1]. When infected vector insects probe plant tissues in search of the vascular xylem elements and sap contents, $X$. fastidiosa is subsequently transmitted to healthy plants. Once in the plant xylem, $X$. fastidiosa is postulated to migrate, attach, aggregate, and form biofilm that clogs the vessels leading to disease development.

\footnotetext{
* Correspondence: mowery@hws.edu

${ }^{2}$ Department of Biology, Hobart and William Smith Colleges, Geneva, NY 14456, USA

Full list of author information is available at the end of the article
}

$X$. fastidiosa migrate via twitching motility against the transpiration stream [2], which involves the extension and retraction of polar localized type IV pili [3]. X. fastidiosa cells are proposed to then attach to the xylem wall mainly using non fimbrial adesins, such as XadA (Xanthomonas adhesin-like protein $\mathrm{A}$ ) and hemagglutinin proteins $\mathrm{HxfB}$ (hemagglutinin Xylella fastidiosa B) [4]. Cell-to-cell adhesion then occurs via non fimbrial adhesins HxfA, HxfB, XatA (Xylella fastidiosa autotransporter A) and the X. fastidiosa type I pili [4-7]. Type I pili co-reside at the cell pole with the long, fewer, type IV pili [8]. Finally biofilm formation commences [9].

To study the roles of $X$. fastidiosa genes and their encoded proteins, researchers traditionally delete $X$. 
fastidiosa genes using transposons or directed deletion with antibiotic-resistant markers $[8,10]$. These processes rely on identifying the mutant strain through antibiotic selection. $X$. fastidiosa Temecula 1 is sensitive to ampicillin, chloramphenicol, gentamicin, kanamycin, novobiocin, rifampin, and tetracycline [11]. Therefore plating transformants on these antibiotics should theoretically provide appropriate selectable markers for differentiation between wild-type $X$. fastidiosa and mutant strains. We recently discovered that nontransformed $X$. fastidiosa strains can survive on selectable medium, presumably due to spontaneous antibiotic-resistant mutants and/or extensive bacterial aggregation between transformed and non-transformed strains. As a result, strains presumed to be mutant clones are often a mixture of mutant and non-transformed $X$. fastidiosa, and over time, the nontransformed $X$. fastidiosa can become a significant population within a mixed sample.

\section{Methods}

\section{Bacteria growth conditions}

Wild-type $X$. fastidiosa Temecula 1 (kanamycin-susceptible) cells were grown on Periwinkle wilt (PW) agar [12] at $28^{\circ} \mathrm{C}$ for 7-10 days, in the absence of phenol red and with $3.5 \mathrm{~g} / \mathrm{L}$ of bovine serum albumin (Invitrogen, Carlsbad, CA). X. fastidiosa mutants were grown on PW amended with kanamycin $(50 \mu \mathrm{g} / \mathrm{mL})$ (Sigma, St. Louis, MO). Cells were stored at $-80^{\circ} \mathrm{C}$ in PD2 (Pierce's Disease 2) media [13] with 7\% DMSO (dimethyl sulfoxide).

\section{Construction of $X$. fastidiosa pilJ mutant}

The pilJ mutant was constructed by double cross over recombination resulting in replacement of the pilJ gene with a kanamycin cassette as preciously described [10]. Approximately 500 bp (base pair) were amplified upstream and downstream of the pilJ gene using primers pilJA/pilJB and pilJC/pilJD respectively (Table 1 ). All primers were purchased from Sigma or Integrated DNA Technologies (Coralville, IA). The polymerase chair reaction (PCR) conditions were as follows: denaturation at $95^{\circ} \mathrm{C}$ for 2 min., 35 cycles of denaturation at $95^{\circ} \mathrm{C}$ for 30 sec., annealing at $55^{\circ} \mathrm{C}$ for $45 \mathrm{sec}$., and extension at $72^{\circ} \mathrm{C}$ for $1 \mathrm{~min}$., followed by $72^{\circ} \mathrm{C}$ for $3 \mathrm{~min}$. A 1-kb fragment was generated from the upstream and downstream fragment using splice extension overlap PCR using the conditions mentioned above with some modifications. Only the pilJA/pillD primers were used with an annealing temperature of $63.5^{\circ} \mathrm{C}$. The $1-\mathrm{kb}$ fragment was cloned into pUC19 plasmid (Invitrogen) to generate pUC19-pilJ. A kanamycin cassette cloned from Topo vector pCR2.1 (Invitrogen) was excised from pGEM T-Easy (Promega, Madison, WI) using flanking the AscI restriction sites. The pUC19-pilJ plasmid was digested with AscI and the kanamycin cassette inserted into the $1 \mathrm{~kb}$ fragment. The presence of the pilJ deletion construct in pUC19 was confirmed by PCR. One microliter of the deletion construct was transformed into electro-competent $X$. fastidiosa [14]. Transformed cells were incubated in $1 \mathrm{~mL}$ PD2 broth for $24 \mathrm{hr}$ before being plated onto PW agar plates amended with kanamycin $(10 \mu \mathrm{g} / \mathrm{mL})$ for 7-10 days. Target gene deletion was verified by PCR, using primers pilJA/pilJD or pilJE/pilJF, and the strain with pilJ gene deleted was designated Xf $\Delta$ pilJ.

PCR amplification of DNA to confirm deletion of pilJ gene The PCR mix included $100 \mathrm{ng}$ of DNA, $200 \mathrm{mM}$ dNTP (deoxyribonucleotide triphosphates), $2 \mathrm{mM} \mathrm{MgSO}_{4}, 0.5 \mathrm{U}$ Platinum Taq (Invitrogen), and $40 \mathrm{nM}$ each of primer (pilJA/pilJD or pilJE/pilJF) in a $25 \mu \mathrm{L}$ reaction mixture. PCR conditions were as follows: denaturation at $95^{\circ} \mathrm{C}$ for $2 \mathrm{~min}$., 35 cycles of denaturation at $95^{\circ} \mathrm{C}$ for $45 \mathrm{sec}$., annealing at $60^{\circ} \mathrm{C}$ for $15 \mathrm{sec}$, and extension at $72^{\circ} \mathrm{C}$ for $2 \mathrm{~min}$. and $30 \mathrm{sec}$., followed by $72^{\circ} \mathrm{C}$ for $6 \mathrm{~min}$. PCR fragments were separated by gel electrophoresis and visualized using the Bio-Rad GelDoc XR system (Bio-Rad, Hercules CA).

\section{Real-time (RT) PCR amplification to confirm deletion of pilJ gene}

The real time PCR mix included $12.5 \mu \mathrm{L}$ SybrGreen real-time PCR mix (Bio-Rad) and 40nM of each primer

Table 1 Oligonucleotide primers used in this study

\begin{tabular}{|c|c|c|c|}
\hline Primer name & Primer sequence $5^{\prime}-3^{\prime}$ & Function & Reference \\
\hline pilJA & ACCTGACTGTTCATCTGATGCG & Deletion of the pilJ gene and confirmation of deletion & This publication \\
\hline \multirow[t]{2}{*}{ pilJB } & TTCGGCGCGCCGAATCTAAATATGC & Deletion of the pilJ gene & This publication \\
\hline & AAGACGGGACCG & & \\
\hline \multirow[t]{2}{*}{ pilJC } & TTCGGCGCGCCGAAATGCTCTCGG & Deletion of the pilJ gene & This publication \\
\hline & CTTGGAAAGGA & & \\
\hline pilJD & CGCAGCACGGATCTCGTTAA & Deletion of the pilJ gene and confirmation of deletion & This publication \\
\hline pilJE & CCCGAGTACCAACTITGGATTG & Amplification of pilJ gene fragment & This publication \\
\hline pilJF & ATCTGCTCATCCTITCCAAGCC & Amplification of pilJ gene fragment & This publication \\
\hline RST31 & GCGTTAATTTCGAAGTGATTCGAT TGC & Xylella fastidiosa detection & {$[17]$} \\
\hline RST33 & CACCATTCGTATCCCGGTG & Xylella fastidiosa detection & {$[17]$} \\
\hline
\end{tabular}


in a total of $25 \mu \mathrm{L}$. PCR conditions include denaturation at $95^{\circ} \mathrm{C}$ for $3 \mathrm{~min}$., and 35 cycles of $95^{\circ} \mathrm{C}$ for 10 sec., $50^{\circ} \mathrm{C}$ for $5 \mathrm{sec}$., $72^{\circ} \mathrm{C}$ for $25 \mathrm{sec}$. The melt curve was calculated at $76-95^{\circ} \mathrm{C}$ with $0.5^{\circ} \mathrm{C}$ increments for $5 \mathrm{sec}$.

\section{Bacterial aggregation}

Bacteria, Escherichia coli or X. fastidiosa, were grown on Luria Bertani (LB) or PW agar plates. Cells were removed from the plates and suspended in succinate-citratephosphate (SCP) buffer [15] to an $\mathrm{OD}_{600}$ of $0.10\left(4 \times 10^{7}\right.$ $\mathrm{CFU} / \mathrm{mL}$ ). The cells were suspended vigorously by vortex mixer (Fisher Scientific, Springfield, NJ) for 5 minutes at maximum speed and by pipetting before being observed for aggregates. Cells were examined on a Axioskop 2 Plus microscope (Carl Zeiss Microscopy, Thornwood, NY) with a QImaging Retiga Exi camera (QImaging, Surrey, Canada) at 40X using QCapture 2.9.13 software (QImaging).

\section{Mutant and wild-type $X$. fastidiosa on antibiotics}

Wild-type $X$. fastidiosa and the Xf $\Delta$ pilJ mutant cells were grown to an $\mathrm{OD}_{600}$ of 0.10 in $\mathrm{PD} 2$ liquid media. The Xf $\Delta$ pilJ mutant was a pure mutant having undergone multiple rounds of isolation followed by RT-PCR confirmation of not containing mixed populations. Wild-type bacteria, the Xf $\Delta$ pilJ mutant, or equal concentrations of both were suspended in PD2 media and incubated at $28^{\circ} \mathrm{C}$ for $24 \mathrm{hr}$, as occurs during a transformation [14]. After incubation, $100 \mu \mathrm{L}$ was plated onto PW agar plates containing $0,4,10,25$, or $50 \mu \mathrm{g} / \mathrm{mL}$ kanamycin, and plates were incubated for 7-10 days at $28^{\circ} \mathrm{C}$ until growth was visible. Bacteria were scraped and collected from each plate and conventional PCR was conducted, as previously described. The PCR fragments obtained were analyzed by gel electrophoresis and visualized using the Bio-Rad GelDoc XR system (Bio-Rad). The experiment was performed three times.

\section{Results and discussion}

The pilJ gene encodes a putative chemotaxis receptor of interest [16]. The gene was deleted from $X$. fastidiosa Temecula 1 using site directed replacement with a kanamycin resistant marker [10]. Transformants were selected on antibiotic plates at $10 \mu \mathrm{g} / \mathrm{mL}$ since the minimum inhibitory concentration of kanamycin for $X$. fastidiosa Temecula 1 is $4 \mu \mathrm{g} / \mathrm{mL}$ [11]. All subsequent work with the transformed cells (Xf $\Delta$ pilJ mutants) were performed with $50 \mu \mathrm{g} / \mathrm{mL}$ kanamycin. Deletion of the pilJ gene was confirmed by PCR using multiple primer sets (Figure 1). The pilJA/pilJD (AD) primers amplified a 3082 bp band from wild-type control bacteria and a $2200 \mathrm{bp}$ band from the deletion plasmid pUC19-pilJ and the XfspilJ strain (Figure 2). The pilJE/pilJF (EF) primers are complementary to sequences within the pilJ gene producing a $2030 \mathrm{bp}$ band for wild-type control cells and no fragments for the $\mathrm{Xf} \Delta$ pilJ bacteria or plasmid control. The X. fastidiosa-specific RST31/33 primers [17] confirmed that the bacteria were $X$. fastidiosa. As expected, these primers failed to amplify a band from the pUC19-pilJ plasmid. The Xf $\Delta$ pilJ strain was subsequently tested in a number of behavioral assays to explore the role of the PilJ protein (data not shown). The $\mathrm{Xf} \Delta$ pilJ strain was placed in storage at $-80^{\circ} \mathrm{C}$ in PD2 with 7\% DMSO.

The Xf $\Delta$ pilJ strain was streaked onto $\mathrm{PW}$ agar plates amended with kanamycin after $-80^{\circ} \mathrm{C}$ storage. The Xf $\Delta$ pilJ mutant was observed to have behavioral phenotypes different from that previously observed for the mutant before storage but similar to wild-type $X$. fastidiosa (data not shown). The genotype of the Xf $\Delta$ pilJ mutant was therefore assessed by PCR. Xf $\Delta$ pilJ mutant directly from the $-80^{\circ} \mathrm{C}$ stock was streaked onto PW agar plates with kanamycin to obtain single colonies and assessed by PCR. Of the twelve single colonies analyzed with the EF primers, 11 gave bands suggestive of non-
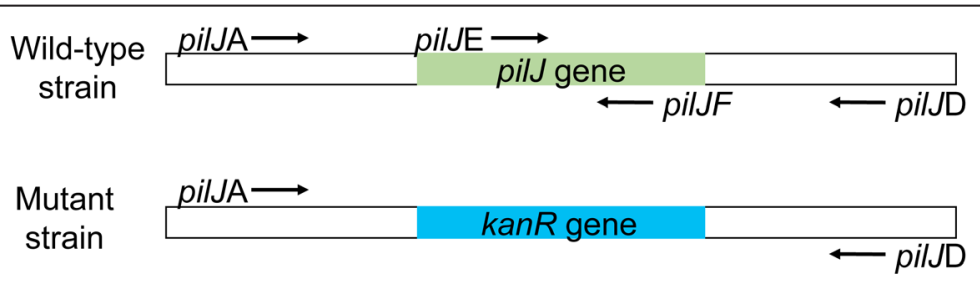

\begin{tabular}{lcc} 
Primer pairs & Wild-type product size (bp) & $\Delta$ pilJ product size $(\mathrm{bp})$ \\
\hline AD & 3082 & 2200 \\
EF & 2030 & no product \\
RST31/33 & 733 & 733
\end{tabular}

Figure 1 Orientation of primers for Xylella fastidiosa pilJ gene deletion. Location of binding sites for PCR primers and length of resulting PCR products for transformed Xf $\Delta$ pilJ strains and for wild-type control or non-transformed cells. RST31/33 are primers specific to X. fastidiosa and used for bacteria confirmation. 


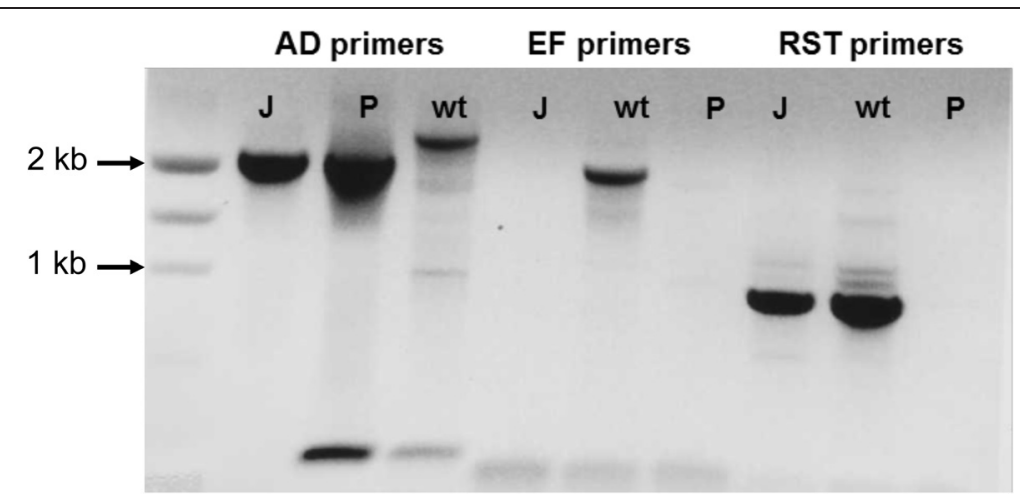

Figure 2 Confirmation of Xylella fastidiosa pilJ gene deletion. The pilJA/pilJD (AD) primers amplify a 3082 bp fragment from wild-type control cells (wt) or a 2200 bp fragment form the Xf $\Delta$ pilJ mutant (J) and deletion plasmid (P). The pilJE/pilJF (EF) primers amplify a 2030 bp band for the wild-type control strain and no band for the mutant cells or deletion plasmid. RST31/33 (RST) primers confirm that the bacteria were X. fastidiosa.

transformed cells (Figure 3). Colony 12, which lacked a fragment with the EF primers, suggesting it was the Xf $\Delta$ pilJ mutant strain, was streaked onto PW-kanamycin for a second round of single colony isolation. Subsequently, 32 colonies from round two were transferred to new PW plates with kanamycin and used for PCR with the AD and EF primer sets (Figure 4). Five colonies (colonies 1, 2, 4, $15,17)$ appeared to be the Xf $\Delta$ pilJ mutant strain, as they did not give a band with the EF primers and had a $2200 \mathrm{bp}$ band with the AD primers, while 11 colonies exhibited results typical of non-transformed cells, as they gave bands with the EF primers and a 3082 bp band with the AD primers. Mixed colonies of non-transformed and transformed cells were also observed (colony 22); where the EF primers amplified a band indicating the non-transformed strain was present, and the AD primers amplified a mutant size band indicating that the $\mathrm{Xf} \Delta$ pilJ mutant was also present. Samples that appeared to be non-transformed or failed to amplify a band with AD primers, whether they amplified a band with EF primers or not, were not further analyzed. Two of the five transformed colonies were streaked onto PW agar plates with kanamycin to obtain single colonies for a third round of isolation. Of the 16 colonies examined in round three, 13 gave the mutant phenotype with the EF and AD primers (Figure 5). Again, those colonies appearing to be non-transformed, failing to amplify a band with $\mathrm{AD}$ primers, or giving a very small band with the $\mathrm{AD}$ primers were not further examined. Four of the Xf $\Delta p i l J$ mutants were restreaked onto PW with kanamycin and assessed by real-time PCR for the presence of the pilJ gene (data not shown). None of these colonies were positive for the pilJ gene, therefore the samples were stored at $-80^{\circ} \mathrm{C}$ in PD2 with 7\% DMSO. This phenomenon of contamination by non-transformed cells was not limited to the Xf $\Delta$ pilJ mutant strain, but observed with a number of our $X$. fastidiosa deletion mutants (data not shown).

Mixtures of constructed kanamycin-resistant Xf $\Delta$ pilJ mutant and non-transformed strains may have occurred due to spontaneous antibiotic resistant mutation in wild-type cells, high aggregation rate of $X$. fastidiosa, or a combination of both events. The ability of bacteria to develop spontaneous resistance to antibiotics is a well known

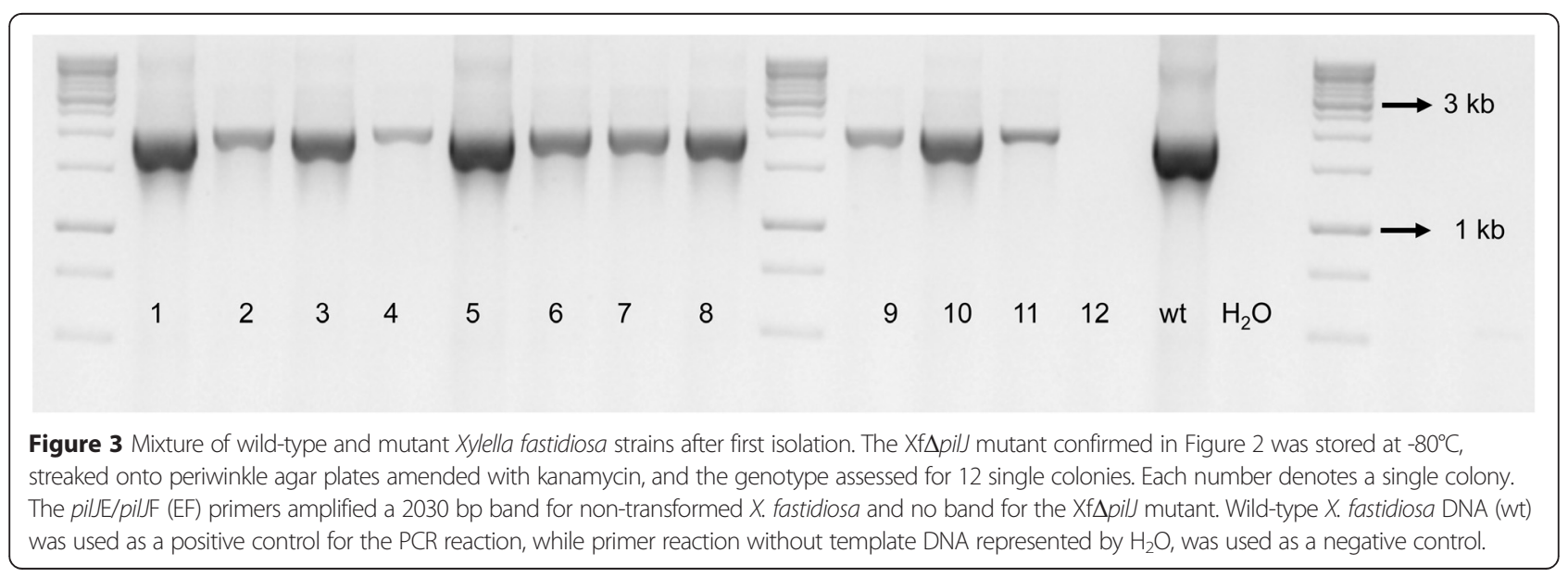




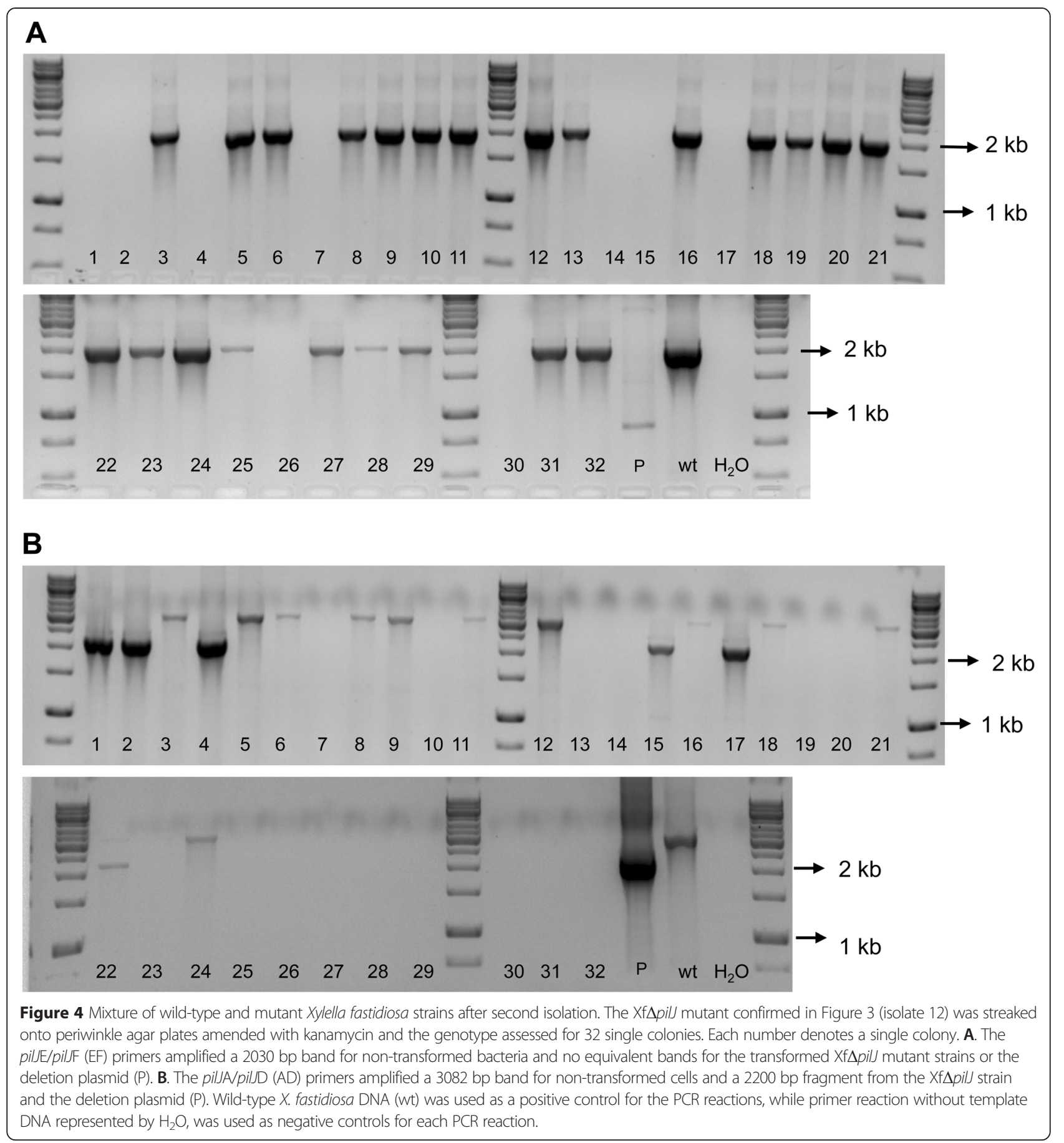

phenomenon [18]. Sub-optimal antibiotic conditions provide particularly favorable conditions for these mutant strains to emerge. Of note, $X$. fastidiosa mutants were grown at standard, not sub-optimal, kanamycin concentrations [11]. Mixed aggregates of susceptible wild-type with kanamycin-resistant constructed Xf $\Delta$ pilJ mutant strains may also explain the findings. X. fastidiosa characteristically and spontaneously forms aggregates that are not easily dispersed, compared to bacteria such as Escherichia coli, even after vigorous resuspension by mixing and pipetting (Figure 6). Presumably both aggregated and planktonic cells were transformed during mutant generation, and mixed aggregates of transformed and non-transformed cells formed subsequently. The aggregate formation may result in decreased susceptibility to antibiotics by the non-transformed bacteria $[19,20]$. After transformation when plating onto selective media (kanamycin) non-transformed bacteria may be "protected" from 


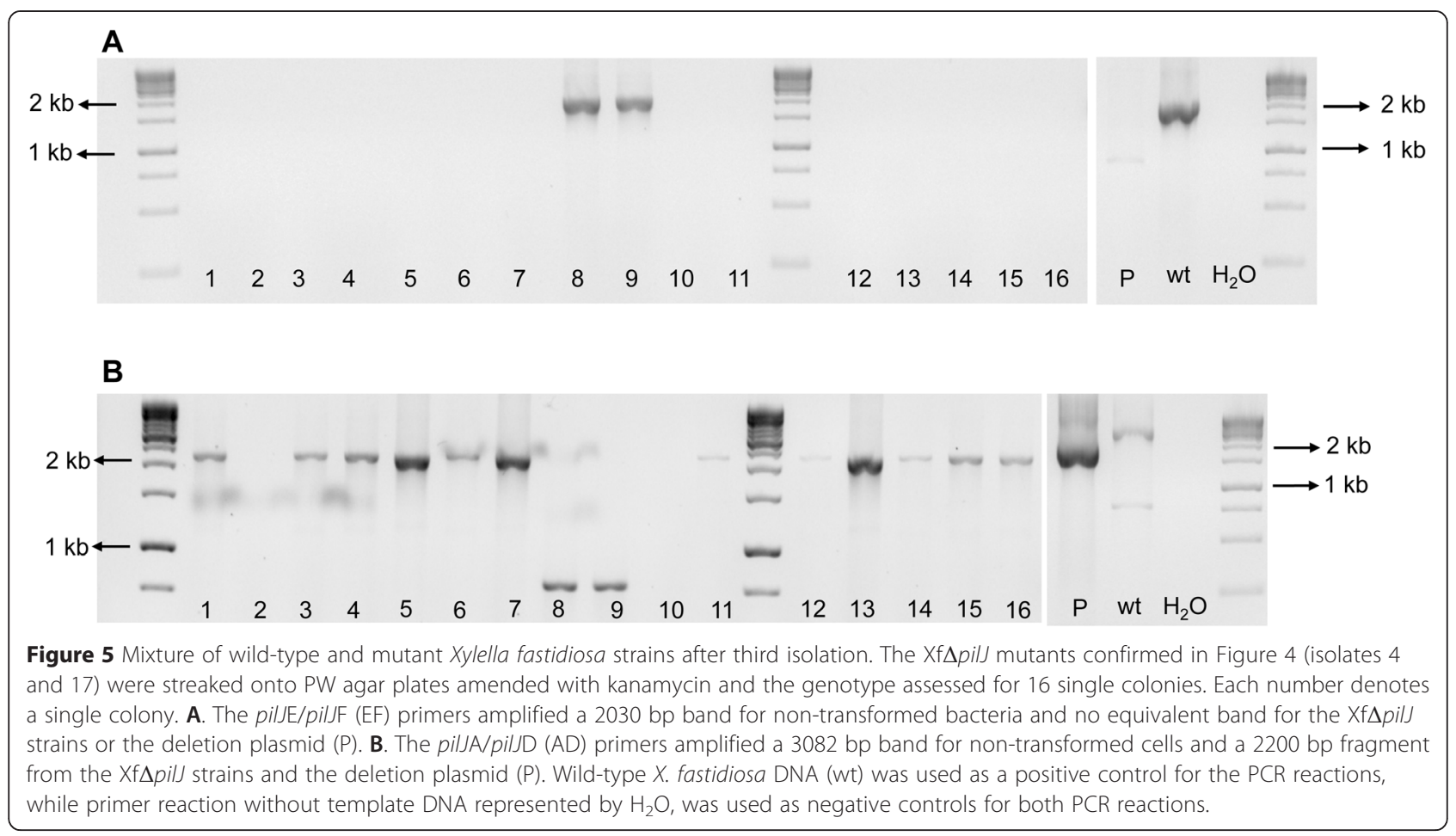

antibiotics by antibiotic resistant bacteria present in the aggregate, as is found in biofilms [21].

We tested the importance of mutants protecting wildtype bacteria from antibiotics by growing cells (wild-type $X$. fastidiosa, Xf $\Delta$ pilJ mutant strain, or an equal mixture) for 24 hours and plating them on PW with various concentrations of kanamycin, as is done for transformations. The wild-type-only $X$. fastidiosa sample gave the expected bands with all the primers tested when grown on $0 \mu \mathrm{g} / \mathrm{mL}$ of kanamycin (Figure 7). At higher concentrations of antibiotics no bacterial growth was observed on agar plates, therefore PCR could not be conducted. The Xf $\Delta$ pilJ-only mutant sample grew on all concentrations of antibiotics tested and gave the expected fragments with the AD and
RST primers, while the EF primers did not produce a fragment, as expected. In one of three trials, PCR analysis of the plated mixed colonies of wild-type and the Xf $\Delta$ pilJ mutant showed the presence of both strains; AD primers amplified the Xf $\Delta$ pilJ mutant 2200 bp band, and the EF primers amplified a wild-type 2030 bp band at all concentrations of antibiotics tested except $10 \mu \mathrm{g} / \mathrm{mL}$. These results indicate the presence of a small number of wild-type bacteria even on PW agar plates containing $50 \mu \mathrm{g} / \mathrm{mL}$ of kanamycin. While spontaneous antibiotic resistance cannot be ruled out, our results suggest that protection of the wild-type strain in mixed cell populations readily occurs, particularly as no wild-type-only samples grew on any kanamycin concentrations. In addition, the fact that the

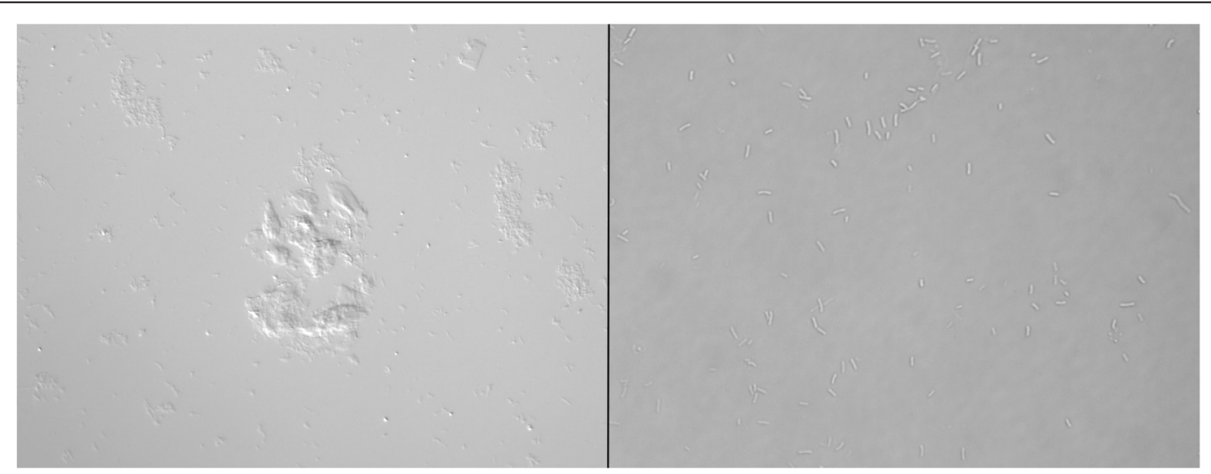

Figure 6 Aggregation of Xylella fastidiosa and Escherichia coli. A suspension of X. fastidiosa (left) or E. coli (right) in SCP buffer five minutes after vigorous resuspension by vortexing and pipetting. Twenty microliters was pipetted onto slides and viewed by microscopy at 40X. While E. coli cells dispersed, $X$. fastidiosa present as aggregates, and could not be evenly dispersed. 


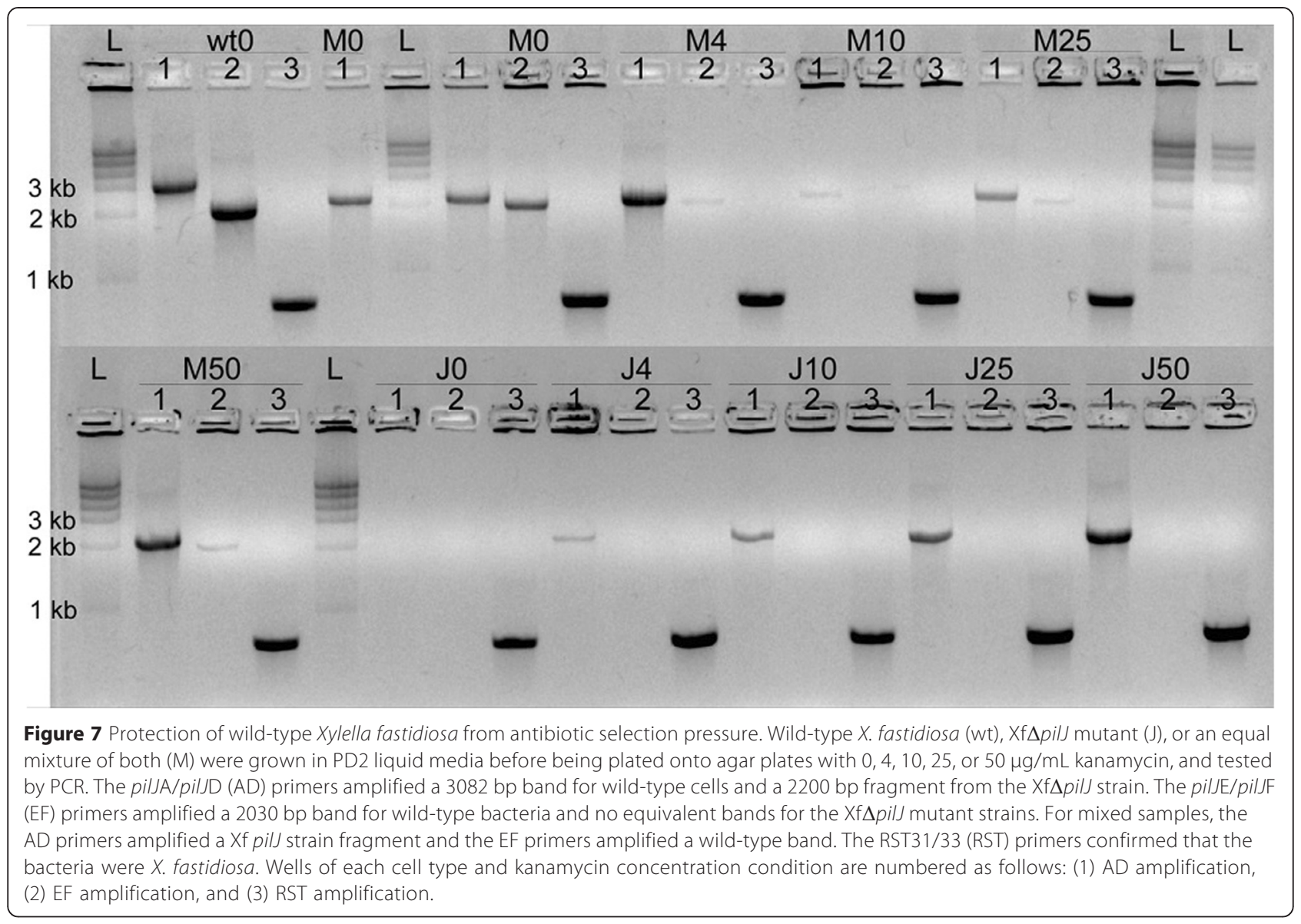

wild-type EF band was faint and not observed on one kanamycin PW plate $(10 \mu \mathrm{g} / \mathrm{mL}$ concentration) may indicate that in our original findings (Figure 2) the number of wild-type cells in the mixed population may have been below detection level by conventional PCR.

Overall, it is possible that following transformation, colonies on selection plates may not have arisen from a single cell but from an aggregate containing a mix of the transformed and non-transformed cells. The presumed Xf $\Delta$ pilJ mutant clone was then stored in PW amended with 7\% DMSO. After thawing and refreezing the nontransformed bacteria present may grow and attain populations that can affect the overall population dynamics and skew results of phenotypic assays as observed after recovery of stored Xf $\Delta$ pilJ, suggesting they were more fit for the freeze/thaw process.

Various aspects of $X$. fastidiosa aggregation have been reported. X. fastidiosa was found to aggregate into starlike clusters in microfluidic chambers under conditions of xylem flow [5]. The extent of aggregation is known to be dependent on media [22], xylem fluid source [23], and grapevine xylem chemistry [24]. Calcium can increase the ability of the bacterium to form aggregates while calcium chelators, such as ethylene glycol tetraacetic acid (EGTA) and 1,2-bis (o-aminophenoxy)ethane- $N, N, N^{\prime}, N^{\prime}$-tetraacetic acid acetoxymethyl ester (BAPTA/AM), cause a decrease in aggregation [25]. It would be interesting to determine if growth in media that promotes planktonic suspensions, followed by transformation, would reduce the possibility of mixed clones when generating $X$. fastidiosa mutants.

\section{Conclusions}

While it is possible to make targeted deletions in X. fastidiosa, complications may arise due to spontaneous antibiotic resistance and/or cell aggregates formed by the bacteria. The presence of aggregates may allow non-transformed bacteria to survive on PW kanamycin agar plates. At least three passages of single colony isolation followed by PCR may be required to minimize the amount of non-transformed cells contaminating the transformants. It may also be prudent to perform single colony isolation after retrieval from storage before use of mutant strains in assays.

\section{Abbreviations}

AD: primers pilJA and pilJD; BAPTA/AM: 1,2-bis(o-aminophenoxy)ethane-N,N, $N^{\prime}, N^{\prime}$-tetraacetic acid acetoxymethyl ester; bp: basepair; DMSO: dimethyl sulfoxide; EF: primers pilJE and pilJF; EGTA: ethylene glycol tetraacetic acid; 
HxfB: hemagglutinin Xylella fastidiosa B; LB: Luria Bertani; PCR: polymerase chain reaction; PD2: Pierce's Disease 2; PW: Periwinkle wilk; RT: real time; SCP: Succinate-citrate-phosphate; XadA: Xanthomonas adhesin-like protein A; XatA: Xylella fastidiosa autotransporter A..

\section{Competing interests}

The authors declare that they have no competing interests.

\section{Authors' contributions}

$\mathrm{KL}$ collected data and drafted the manuscript, LC collected data, DA created the original mutant, TJB did critical review of the manuscript, and PM critically reviewed, and helped draft the manuscript. All authors approve the final version of the manuscript.

\section{Acknowledgements}

This work was supported, in part, from grants provided through the United States Department of Agriculture Cooperative State Research, Education, and Extension Service administered through the University of California Pierce's disease research grants program to TJB and PM.

\section{Author details}

'Department of Plant Pathology and Plant-Microbe Biology, Cornell University New York State Agricultural Experiment Station, Geneva, NY 14456, USA. 2Department of Biology, Hobart and William Smith Colleges, Geneva, NY 14456, USA. ${ }^{3}$ Current address: Major of Organic Farming Management, Faculty of Science and Technology, Thammasat University, Pathum Thani, Thailand.

Received: 18 August 2014 Accepted: 1 April 2015

Published online: 16 April 2015

\section{References}

1. Chatterjee S, Almeida RP, Lindow S. Living in two worlds: the plant and insect lifestyles of Xylella fastidiosa. Annu Rev Phytopatho. 2008;46:243-71.

2. Meng Y, Li Y, Galvani CD, Hao G, Turner JN, Burr TJ, et al. Upstream migration of Xylella fastidiosa via pilus-driven twitching motility. J Bacterio. 2005:187(16):5560-7.

3. Mattick JS. Type IV, pili and twitching motility. Annu Rev Microbio. 2002;56:289-314.

4. Feil H, Feil WS, Lindow SE. Contribution of fimbrial and afimbrial adhesins of Xylella fastidiosa to attachment to surfaces and virulence to grape. Phytopathology. 2007;97(3):318-24.

5. De La Fuente L, Burr TJ, Hoch HC. Autoaggregation of Xylella fastidiosa cells is influenced by type I and type IV pili. Appl Environ Microbiol. 2008;74(17):5579-82.

6. Matsumoto A, Huston SL, Killiny N, Igo MM. XatA, an AT-1 autotransporter important for the virulence of Xylella fastidiosa Temecula1. Microbiology. 2012;1(1):33-45.

7. Guilhabert MR, Kirkpatrick BC. Identification of Xylella fastidiosa antivirulence genes: hemagglutinin adhesins contribute a biofilm maturation to $X$. fastidiosa and colonization and attenuate virulence. Mol Plant Microbe Interact. 2005;18(8):856-68.

8. Li Y, Lao G, Galvin CD, Meng Y, De La F, Hoch HC, et al. Type I and type IV pili of Xylella fastidiosa affect twitching motility, biofilm formation and cell-cell aggregation. Microbiology. 2007;153(Pt 3):719-26.

9. Caserta R, Takita MA, Targon ML, Rosselli-Murai LK, de Souza AP, Peroni L, et al. Expression of Xylella fastidiosa fimbrial and afimbrial proteins during biofilm formation. Appl Environ Microbiol. 2010;76(13):4250-9.

10. Shi XY, Dumenyo CK, Hernandez-Martinez R, Azad H, Cooksey DA. Characterization of regulatory pathways in Xylella fastidiosa: genes and phenotypes controlled by gacA. Appl Environ Microbiol. 2009;75(8):2275-83.

11. Kuzina LV, Miller TA, Cooksey DA. In vitro activities of antibiotics and antimicrobial peptides against the plant pathogenic bacterium Xylella fastidiosa. Lett Appl Microbiol. 2006;42(5):514-20.

12. Davis MJ, French WJ, Schaad NW. Axenic culture of the bacteria associated with phony disease of peach and plum leaf scald. Curr Microbiol. 1981;6:309-14.

13. Davis MJ, Purcell AH, Thomson SV. Isolation media for the Pierce's disease bacterium. Phytopathology. 1980;70:425-9.

14. Guilhabert MR, Hoffman LM, Mills DA, Kirkpatrick BC. Transposon mutagenesis of Xylella fastidiosa by electroporation of Tn5 synaptic complexes. Mol Plant Microbe Interact. 2001;14(6):701-6.
15. Hopkins DL. Variability of virulence in grapevine among isolates of the Pierce's disease bacterium. Phytopathology. 1984;74(11):1395-8.

16. Cursino L, Galvani CD, Athinuwat D, Zaini PA, Li Y, De La Fuente L, et al. Identification of an operon, Pil-Chp, that controls twitching motility and virulence in Xylella fastidiosa. Mol Plant Microbe Interact. 2011;24(10):1198-206.

17. Minsavage GV, Thompson CM, Hopkins DL, Leite RMVBC, Stall RE. Development of a polymerase chain reaction protocol for detection of Xylella fastidiosa in plant tissue. Phytopathology. 1994;84:456-61.

18. Wright GD. The antibiotic resistome: the nexus of chemical and genetic diversity. Nat Rev. 2007;5(3):175-86.

19. Thornton MM, Chung-Esaki HM, Irvin CB, Bortz DM, Solomon M, Younger JG. Multicellularity and antibiotic resistance in Klebsiella pneumonia grown under bloostream-mimicking fluid dynamic conditions. J Infect Dis. 2012;206(4):588-95.

20. Alhede M, Kragh KN, Qvortrup K, Allesen-Holm M, van Gennip M, Christensen $\mathrm{LD}$, et al. Phenotypes of non-attached Pseudomonas aeruginosa aggregates resemble surface attached biofilm. PLoS One. 2011;6(11):e27943.

21. de la Fuente-Nunez C, Reffuveille F, Fernandez L, Hancock RE. Bacterial biofilm development as a multicellular adaptation: antibiotic resistance and new therapeutic strategies. Curr Opin Microbiol. 2013;16(5):580-9.

22. Leite $B$, Andersen PC, Ishida ML. Colony aggregation and biofilm formation in xylem chemistry-based media for Xylella fastidiosa. FEMS Microbiol Lett. 2004;230(2):283-90.

23. Bi JL, Dumenyo CK, Hernandez-Martinez R, Cooksey DA, Toscano NC. Effect of host plant xylem fluid on growth, aggregation, and attachment of Xylella fastidiosa. J Chem Ecol. 2007;33(3):493-500.

24. Andersen PC, Brodbeck BV, Oden S, Shriner A, Leite B. Influence of xylem fluid chemistry on planktonic growth, biofilm formation and aggregation of Xylella fastidiosa. FEMS Microbiol Lett. 2007;274(2):210-7.

25. Cruz LF, Cobine PA, De La Fuente L. Calcium increases Xylella fastidiosa surface attachment, biofilm formation, and twitching motility. Appl Environ Microbiol. 2012;78(5):1321-31.

\section{Submit your next manuscript to BioMed Central and take full advantage of:}

- Convenient online submission

- Thorough peer review

- No space constraints or color figure charges

- Immediate publication on acceptance

- Inclusion in PubMed, CAS, Scopus and Google Scholar

- Research which is freely available for redistribution 